\title{
Comparative study of various tocolytics in preterm labour
}

\author{
Neetu Singh *, Preeti Dubey, Neena Gupta, Seema Dwivedi, \\ Rashmi Balyan, Ani Chandanan
}

Department of Obstetrics and Gynaecology, GSVM Medical College, Kanpur, UP, India

Received: 07 January 2015

Accepted: 14 February 2015

\section{*Correspondence:}

Dr. Neetu Singh,

E-mail: drneetusingh73@gmail.com

Copyright: (c) the author(s), publisher and licensee Medip Academy. This is an open-access article distributed under the terms of the Creative Commons Attribution Non-Commercial License, which permits unrestricted non-commercial use, distribution, and reproduction in any medium, provided the original work is properly cited.

\begin{abstract}
Background: Preterm birth is one of the major factors responsible for neonatal mortality and morbidity. In this study, we have to see the role of various tocolytics in preventing preterm labour.

Methods: The observational study was conducted on 200 patients admitted in Upper India Sugar Exchange Maternity Hospital, Kanpur.

Results: In our study calcium channel blocker were associated with statistically and clinically significantly better neonatal outcome and fewer maternal side effects than any other tocolytic. So calcium channel blocker would be preferred first line tocolytic with regard to several important outcomes.

Conclusions: Preterm birth continued to be problem for obstetrician. Administration of short term tocolytic agents can prolong pregnancy for women in pre-term labor. Prolonging pregnancy may have benefits because it allows for other proven interventions, such as antenatal corticosteroid administration to be accomplished. The reviews proven an overview currently utilize tocolytic agents and the evidence of demonstrating their efficacy for prolonging pregnancy by at least 48 hours.
\end{abstract}

Keywords: Tocolytics, Short-term, Preterm delivery

\section{INTRODUCTION}

Preterm birth continues to be a problem for obstetricians. Preterm birth complicates $8-10 \%$ of birth. ${ }^{1}$ Although the causes of preterm labour are not well understood, the burden of preterm birth is clear. The majority of neonatal deaths and over one third of infant deaths are linked to preterm birth. Methods to detect preterm labour at early stage include ultrasound examination of cervix and detection of biochemical markers of preterm labour in blood, saliva and cervicovaginal secretion. Given the methods to predict and prevent preterm birth are imperfect, attention focuses on the treatment of women admitted with preterm labour. The most beneficial intervention in these cases is antenatal corticosteroid. Antenatal corticosteroids have been clearly demonstrated to reduce neonatal mortality and multiple morbidities.
Thus the primary goal of tocolytic therapy has been to maintain the pregnancy for at least 48 hours to enable administration of antenatal corticosteroid. No evidence exists that tocolytic therapy directly benefits neonatal outcomes. However, short term tocolytic therapy has been demonstrated to be superior to placebo in prolonging pregnancy for at least 48 hours. David M Haas et al. described the role of short term tocolytics for preterm deliveries. $^{2}$ Short-term use of tocolytic drugs is common in order to prolong pregnancy long enough for effective antenatal corticosteroids and other therapies to be administered. Multiple classes and drugs are utilized, mainly because many demonstrate similar efficacy. Recent systematic reviews and meta-analyses have demonstrated that prostaglandin inhibitors tend to have the best probability of delaying delivery by at least 48 hours, while calcium channel blockers may be superior in 
preventing neonatal complication. However, these results are from meta-analyses and not direct trials using all drug classes and thus must be interpreted carefully. In addition, because of concerns about premature closure of the fetal ductus, prostaglandin inhibitors are seldom used in practice after 32 week. Short-term tocolytic therapy should be individualized to the patient and her particular circumstances and the potential for side effect. Pharmacogenetic principles have been explored in relation to tocolytic drugs like nifedipine. These may give us a glimpse into the future of obstetric therapeutics and more individualization of pharmacotherapy during pregnancy. No matter which tocolytic agent the clinician chooses, the evidence supports the use of short-term tocolytic drugs to prolong pregnancy for at least 48 hours to allow for administration of antenatal steroids. This may also allow for transport of the mother to a tertiary care facility and for administration of magnesium sulfate to reduce the risk of cerebral palsy. While many trials have used tocolytics for longer periods of time, those that analyzed prolonged courses of tocolytics have generally failed to demonstrate benefit. So while the choice of firstline agent may not be clear, it is evident that short-term tocolysis is an effective and helpful therapy for women in preterm labor.

\section{METHODS}

This observational study was done in patients of preterm labour in Upper India Sugar Exchange Maternity Hospital, Kanpur. Present study comprised of a total of 200 cases of preterm labour. Out of these, 60 patients were treated with ritodrine, 50 with isoxsuprine, 30 with nifedepine, 30 with glyceryltrinitrate and 30 with magnesium sulphate.

Following were with exclusion criteria of present study:

- Multiple gestation

- A plan to move out of the area before delivery

- History of associated infection and inflammation

- Hormone use

- Metabolic syndrome

- Medication use (particularly statins, fibrates, neacin)

- Cardiovascular disease

\section{RESULTS}

In our study calcium channel blocker were associated with statistically and clinically significantly better neonatal outcomes and fewer maternal side effects than any other tocolytic so calcium channel blocker would be preferred first line tocolytic with regard to several important outcomes.

Table 1: Demographic profile of patient.

\begin{tabular}{|c|c|c|c|c|c|}
\hline Characteristics & Ritodrine & Isoxsuprine & Nifedepine & GTN & $\mathrm{MgSO}_{4}$ \\
\hline $\begin{array}{l}\text { Mean Age } \\
\text { (year) }\end{array}$ & $\begin{array}{l}22.78 \pm \\
8.05\end{array}$ & $\begin{array}{l}23.80 \pm \\
8.06\end{array}$ & $\begin{array}{l}24.56 \pm \\
8.08\end{array}$ & $\begin{array}{l}23.75 \pm \\
8.06\end{array}$ & $\begin{array}{l}25.25 \pm \\
8.12\end{array}$ \\
\hline \multicolumn{6}{|l|}{ Parity } \\
\hline P0 & 8.3 & 12 & 16.6 & 26.6 & 20 \\
\hline $\mathrm{P} 1$ & 25 & 20 & 16.6 & 20 & 23.3 \\
\hline $\mathrm{P} 2$ & 41.6 & 40 & 40 & 33.3 & 36.6 \\
\hline P3 & 25 & 28 & 26.5 & 19.8 & 10.9 \\
\hline $\begin{array}{l}\text { No of patients } \\
\text { with low } \\
\text { socioeconomic } \\
\text { status }\end{array}$ & 36 & 30 & 20 & 22 & 25 \\
\hline
\end{tabular}

Table 2: Bishop's Scoring, cervical dilatation, clinical characteristics at the time of admission.

\begin{tabular}{|llllll|}
\hline $\begin{array}{l}\text { Characteristics } \\
\text { Mean Bishop's }\end{array}$ & Ritodrine & Isoxsuprine & Nifedepine & GTN & MgSO $_{4}$ \\
score & $4.5 \pm 2.46$ & $4.36 \pm 2.65$ & $4.4 \pm 2.65$ & $4.7 \pm 2.62$ & $4.6 \pm 2.63$ \\
\hline \multicolumn{2}{l}{ Initial cervical dilatation in cm } & & & & \\
\hline$<2 \mathrm{~cm}$ & $83.3 \%$ & $88 \%$ & $83.3 \%$ & $86.6 \%$ & $80 \%$ \\
\hline$>2 \mathrm{~cm}$ & $16.6 \%$ & $12 \%$ & $16.6 \%$ & $13.3 \%$ & $20 \%$ \\
\hline Mean GA & $30.23 \pm 2.84$ & $30.52 \pm 2.70$ & $30.06 \pm 2.85$ & $30.60 \pm 2.83$ & $30.0 \pm 2.85$ \\
\hline
\end{tabular}


Table 3: Relationship of gestational age with outcome of tocolysis.

\begin{tabular}{|lccccc|}
\hline $\begin{array}{l}\text { Mean Gestational } \\
\text { age } \\
\text { (weeks) }\end{array}$ & Ritodrine & Isoxsuprine & Nifedepine & GTN & MgSO $_{4}$ \\
$\begin{array}{l}\text { Gestational age on } \\
\begin{array}{l}\text { admission } \\
\text { Mean } \pm \text { SD }\end{array}\end{array}$ & $30.23 \pm 2.84$ & $30.52 \pm 2.70$ & $30.06 \pm 2.85$ & $30.60 \pm 2.83$ & $30.0 \pm 2.85$ \\
\hline $\begin{array}{l}\text { Gestational age on } \\
\text { delivery } \\
\text { Mean } \pm \text { SD }\end{array}$ & $35.36 \pm 2.98$ & $35.08 \pm 2.95$ & $35.00 \pm 2.94$ & $34.6 \pm 3.55$ & $35.86 \pm 3.83$ \\
\hline
\end{tabular}

Table 4: Duration for which pregnancy was prolonged in relation to cervical dilatation in various groups.

\begin{tabular}{|c|c|c|c|c|c|c|c|c|c|c|}
\hline & \multicolumn{2}{|c|}{ Ritodrine } & \multicolumn{2}{|c|}{ Isoxsuprine } & \multicolumn{2}{|c|}{ Nifedepine } & \multicolumn{2}{|c|}{ GTN } & \multicolumn{2}{|c|}{$\mathrm{MgSO}_{4}$} \\
\hline $\begin{array}{c}\text { Initial cervical } \\
\text { dilatation }\end{array}$ & $<2 \mathrm{~cm}$ & $>2 \mathrm{~cm}$ & $<2 \mathrm{~cm}$ & $>2 \mathrm{~cm}$ & $<2 \mathrm{~cm}$ & $>2 \mathrm{~cm}$ & $<2 \mathrm{~cm}$ & $>2 \mathrm{~cm}$ & $<2 \mathrm{~cm}$ & $>2 \mathrm{~cm}$ \\
\hline Time by which & $54.68 \pm$ & $3.1 \pm$ & $51.09 \pm$ & $2.75 \pm$ & $49.38 \pm$ & $64 \pm$ & $48.96 \pm$ & $43 \pm$ & $53.29 \pm$ & $7.16 \pm$ \\
\hline $\begin{array}{c}\text { labour was } \\
\text { postponed (days) }\end{array}$ & 24.16 & 1.76 & 23.66 & 1.75 & 25.49 & 4.77 & 26.25 & 4.18 & 20.51 & 4.2 \\
\hline
\end{tabular}

Table 5: Maternal side effects in various groups.

\begin{tabular}{|llllll|}
\hline S/E $(\%)$ & Ritodrine & Isoxsuprine & Nifedepine & GTN & $\mathrm{MgSO}_{4}$ \\
\hline $\begin{array}{l}\text { Maternal } \\
\text { tachycardia }\end{array}$ & 16 & 16 & 6.6 & 3.3 & - \\
\hline Headache & - & - & 3.3 & 6.6 & 3.3 \\
\hline $\begin{array}{l}\text { Facial flushing \& } \\
\text { warmth }\end{array}$ & 13.3 & 11 & - & 16.6 & 6.6 \\
\hline Hypotension & 3.3 & - & 13.3 & 16.6 & - \\
\hline Nausea, vomiting & - & - & - & - & 3.3 \\
\hline Nervousness & 3.3 & - & - & - & - \\
\hline Palpitation & 1.6 & 2 & - & - & - \\
\hline
\end{tabular}

Table 6: Fetal outcome in various tocolytic groups.

\begin{tabular}{|llllll|}
\hline SW & Ritodrine & Isoxsuprine & Nifedepine & GTN & MgSO$_{4}$ \\
\hline Fetal tachycardia (\%) & 13.3 & 4 & - & - & - \\
\hline Respiration distress (\%) & - & 4 & 6.6 & 10 & 10 \\
\hline Mean Apgar score & $8.1 \pm 2.20$ & $8.2 \pm 2.44$ & $7.9 \pm 2.39$ & $7.9 \pm 2.39$ & $7.6 \pm 2.34$ \\
\hline Mean birth weight (gm) & $2341 \pm 552.1$ & $2215 \pm 560.4$ & $2166 \pm 541$ & $2116 \pm 576.4$ & $2108 \pm 578.2$ \\
\hline
\end{tabular}

\section{DISCUSSION}

Preterm birth continues to be problem for obstetrician. Administration of short term tocolytic agents can prolong pregnancy for women in pre-term labor. Prolonging pregnancy may have benefits because it allows for other proven interventions, such as antenatal corticosteroid administration to be accomplished. The currently utilized tocolytic agents were reviewed for their efficacy in prolonging pregnancy by at least 48 hours. Preterm birth complicates $8-10 \%$ of birth. ${ }^{1}$ Majority of neonatal deaths and over $1 / 3$ rd of infant deaths are linked to preterm birth. In our study most of the patients belonged to low socioeconomic status percentage being $60 \%$
(36/60), 60\% (30/50), 66.6\% (20/30), 73.3\% (22/30) \& $83.3 \%(25 / 30)$ in ritodrine, isoxsuprine, nifedipine, glyceryltrinitrate and magnesium sulphate group respectively (Table 1). Kramer MS et al. studied socioeconomic disparities in preterm birth. ${ }^{3}$ Cigarette smoking is commonly acknowledged to increase the risk of preterm delivery. Low folic acid increases the risk for preterm delivery. In the present study most of the patient were of 20 -29years age group being $60 \%$ (36/60), 60\% (30/50), 66.6\% (20/30), 66.6 (20/30) and 60\% (18/30) in ritodrine, isoxsuprine, nifedepine, glycerlynitrate and magnesium sulphate group respectively (Table 1). The maximum number of patient belonged to second para in our study, percentage being $43.60 \%$ (25/60), $40 \%$ 
(20/50), $40 \%$ (12/30), $33.3 \%$ (10/30) \& 36.6\% (11/30) in each of ritodrine, isoxsuprine, nifedepine, glycerlynitrate and magnesium sulphate group respectively (Table 1). In the present study maximum number of patient's belonged to gestational age group of 28-30 weeks. The mean gestational age on admission was $30.23 \pm 2.84,30.52 \pm$ $2.70,30.06 \pm 2.85,30.60 \pm 2.85$ and $30.00 \pm 2.85$ in ritodrine, isoxsuprine, nifedepine, glycerlynitrate and magnesium sulphate group respectively (Table 2 ). The maximum numbers of patient in present study were having Bishop's score 4-6. Mean Bishop's score was 4.5 $\pm 2.46,4.36 \pm 2.65,4.4 \pm 2.65,4.7 \pm 2.62,4.6 \pm 2.63$ respectively (Table 2 ). In our study the gestational age on admission nifedepine group was $30.06 \pm 2.85$ weeks as compared to $35.00 \pm 2.94$ was on delivery. This was statistically significant. These studies are in accordance with as of King JF et al., who showed that delivery was delayed with nifedepine. ${ }^{4}$ In nifedepine group the duration of prolongation of pregnancy was $49.38 \pm 25.49$ and $64 \pm 4.17$ days with cervical dilatation $>2 \mathrm{~cm}$. This difference was also statistically significant. In glyceryltrinitrate group the duration of prolongation of pregnancy was $53.29 \pm 26.25$ days with cervical dilatation $<2 \mathrm{~cm}$ and $4.3 \pm 4.18$ days with cervical dilatation $>2 \mathrm{~cm}$. This shows that the drug was found to be more effective with lesser cervical dilatation. These were comparable to the results of Lees et al., who reported that patients with cervical $>2 \mathrm{~cm}$ were at higher risk of imminent delivery. ${ }^{5}$ Nifedepine showed an increases in maternal heart rate in $6.6 \%$ patients and hypotension decrease in (diastolic blood prescribe) in $13.3 \%$ patient. Our findings are similar to a study by King et al. ${ }^{4}$ They suggested that calcium channel blocker are associated with statistically and clinically significantly better neonatal outcome and fewer maternal side effect than any other tocolytic so calcium channel blocker would be preferred first line tocolytic with regard to several important outcome. In our study maximum number of babies had Apgar score between 8 and 10 at 5 minute. Mean Apgar score at 5 minute was $8.1 \pm 2.20$,
$8.2 \pm 2.00,7.9 \pm 2.39,7.9 \pm 2.39,7.6 \pm 2.34$ in ritodrine, isoxsuprine, nifedepine, glycerlynitrate and magnesium sulphate group respectively (Table 6). Mean birth weight of babies born to mother were $2341 \pm 552.1,2215 \pm$ $560.4,2166 \pm 541,2116 \pm 576.4$ and $2108 \pm 578.7 \mathrm{gm}$ respectively in ritodrine, isoxsuprine, nifedepine, glycerlynitrate and magnesium sulphate group respectively (Table 6).

Funding: No funding sources Conflict of interest: None declared

Ethical approval: The study was approved by the Institutional Ethics Committee

\section{REFERENCES}

1. Martin JA, Hamilton BE, Ventura SJ, Menacker F, Park MM, Sutton PD. Births: final data for 2001 National Statistics Report 2002;51(2):1-104.

2. Haas DM, Benjamin T, Sawyer R,Quinney SK. Short-term tocolytics for preterm delivery - current perspectives. Int J Womens Health. 2014;6:343-9.

3. Kramer MS, Goulet L, Lydon J, Seguin L, McNamara H, Dassa C, et al. Socio-economic disparities in preterm birth: causal pathways and mechanisms. Paediatr Perinat Epidemiol. 2001;15 Suppl 2:104-23.

4. King JF, Grant A, Keirse MJ,Chalmers I. Betamimetics in preterm labour: an overview of the randomized controlled trials. Br J Obstet Gynaecol. 1988;95(3):211-22

5. Lees CC, Lojacono A, Thompson C, Danti L, Black RS, Tanzi P, et al. Glyceryl trinitrate and ritodrine in tocolysis: an international multicenter randomized study. GTN Preterm Labour Investigation Group. Obstet Gynecol. 1999;94(3):403-8.

DOI: $10.5455 / 2320-1770 . i j r c o g 20150409$

Cite this article as: Singh N, Dubey P, Gupta N, Dwivedi S, Balyan R, Chandanan A. Comparative study of various tocolytics in preterm labour. Int $\mathbf{J}$ Reprod Contracept Obstet Gynecol 2015;4:334-7. 